\title{
Li-Ion Batteries: A Review of a Key Technology for Transport Decarbonization
}

\author{
Daniele Stampatori (1), Pier Paolo Raimondi (1) and Michel Noussan *(1) \\ Fondazione Eni Enrico Mattei, Corso Magenta 63, 20123 Milano, Italy; daniele.stampatori@feem.it (D.S.); \\ pierpaolo.raimondi@feem.it (P.P.R.) \\ * Correspondence: michel.noussan@feem.it
}

Received: 24 April 2020; Accepted: 18 May 2020; Published: 21 May 2020

\begin{abstract}
Lithium ion batteries are experiencing an increased success thanks to their interesting performances, in particular for electric vehicles applications. Their continuous technological improvements in the last years are providing higher energy density and lower manufacturing costs. However, the environmental performance of their supply chain is of paramount importance to guarantee a cleaner alternative to fossil-based solutions on the entire life cycle of the applications. This paper carries out a comprehensive review on the main aspects related to Li-ion batteries manufacturing, to support the readers in understanding the complexity of the subject and the main challenges and opportunities for the future developments of this technology. The paper discusses the expected future demand of batteries; the main aspects related to the supply chain, including existing assets, input materials and alternative technologies; the end-of-life of batteries; the environmental impacts; and the main geopolitical implications.
\end{abstract}

Keywords: lithium batteries; electric vehicles; sustainability; emissions; environment

\section{Introduction}

Electric Vehicles (EVs) are seen worldwide as a potential solution to transport emissions, at both global and local scales. An increased electricity penetration in final uses, when properly coupled to low-carbon electricity sources (e.g., renewables or nuclear), is a viable option to decrease energy-related carbon emissions. Moreover, the fact that EVs have no direct tailpipe emissions can help in improving the air quality of urban environments, which are currently showing very high pollutants concentrations in different countries worldwide [1].

A large-scale deployment of EVs requires a strong modification of current car manufacturers, and the most critical component of an EV is the electricity storage system, i.e., the battery. However, battery manufacturing often accounts for the largest share of both energy consumption and environmental impacts related to the production and operation of EVs.

The industry is currently focused on Li-ion batteries, which have proven to be a reliable technology [2] with potential decreasing costs thanks to manufacturing upscale [3,4]. Different companies worldwide are increasing the Li-ion batteries manufacturing capacities, often through large-scale factories that are sometimes referred to as "giga-factories" (with the US carmaker Tesla being the first company to use such name). As a result, the strong increase in assets to produce Li-ion batteries will likely guarantee their market dominance in the next decade. Any potential technological breakthrough based on other solutions will probably have an impact only on the medium and long term.

In addition to the EV market, Li-ion batteries have been widely used for portable electronics and are being considered for stationary energy storage to support the mismatching between electricity demand and non-dispatchable generation from variable renewable energy sources (RES), mostly from wind and solar. While the EV market is expected to represent the largest share of sales in the next 
decades, the other segments may grow as well. In particular, stationary storage can become an option for the second-life of batteries that have reached the minimum performance requirements for EVs, but can still represent a useful resource for stationary storage. Potential applications include flexibility services at the grid level [5] and behind-the-meter energy storage in buildings [6].

This review paper aims at providing a clear picture of the current situation and the future perspectives for different aspects involved with Li-ion batteries manufacturing, use and end-of-life phases, including the main environmental impacts and the geopolitical implications that are related to the supply chain. This review paper is organized as follows. Section 2 discusses the main drivers of Li-ion battery demand, with particular focus on EVs. Section 3 illustrates the supply chain of the batteries, while Section 4 gives a specific focus on the end-of-life and the potential of batteries recycling. Sections 5 and 6 discuss the aspects of environmental impacts and geopolitics, respectively. Section 7 concludes the paper.

\section{Drivers of Batteries Demand: Trends and Perspectives of EVs Deployment}

The demand of Li-ion batteries in the last years has been strongly driven by EVs sales, whose demand represented two thirds of global battery sales in 2017 and half of the cumulated sales over the period 2013-2017 [7] (see Figure 1). At the same time, while EVs are currently seeing strong increases year-over-year, their share remains marginal when compared with traditional vehicles. Thus, their potential for improvement is still very large.

The International Energy Agency [8] expects a significant increase of EV deployment in the following decades, and they compare different scenarios of EV penetration. By 2030, EV sales are expected to reach 23-43 million vehicles, depending on the scenario, while the total stock could be in the range 130-250 million (excluding two- and three-wheelers). The evolution of the sector, especially at the initial stage, will be strongly dependent on the incentive measures that will be deployed at the country level [9]. The electrification of the car market will likely remain the most significant driver for the development of Li-ion battery manufacturing, although stationary storage may also play a relevant role in the future.

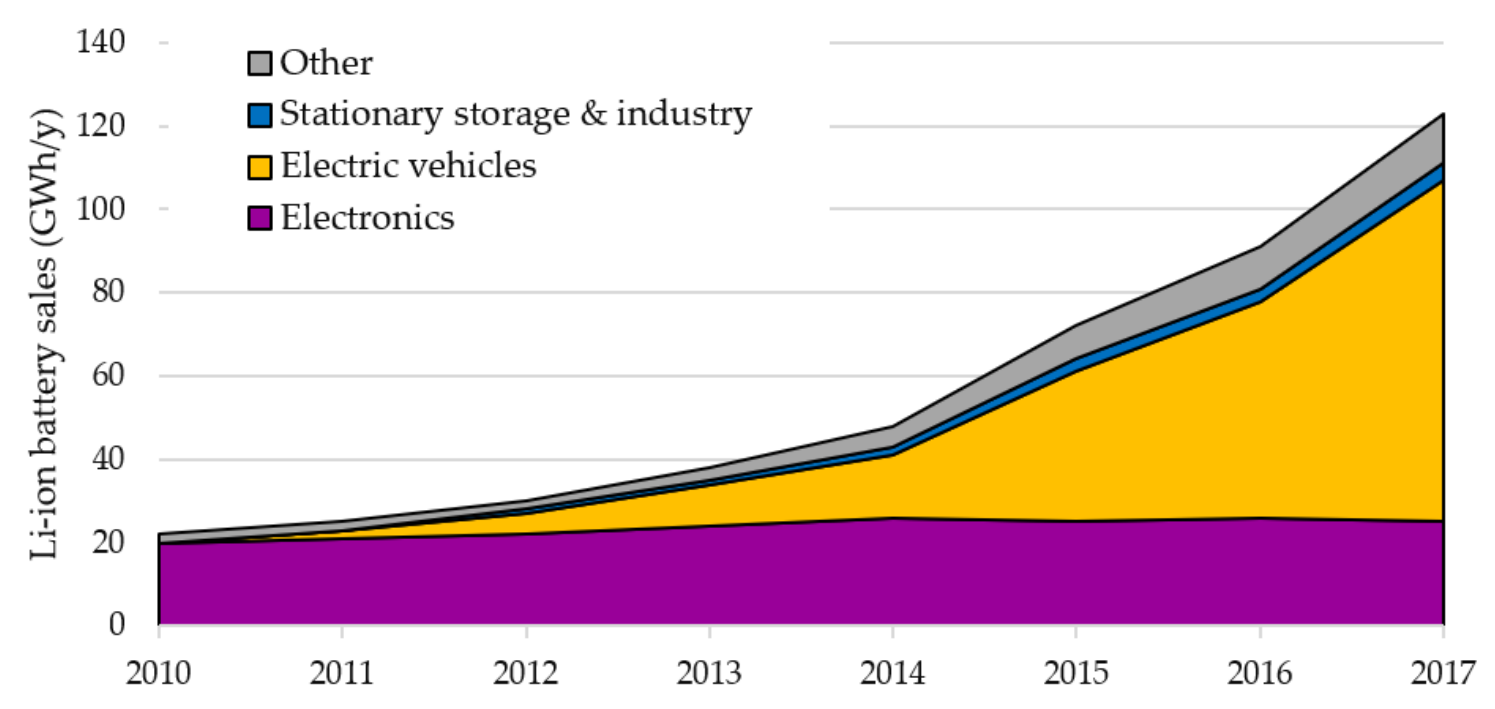

Figure 1. Evolution of Li-ion battery sales per application. Authors' elaboration on [7].

\subsection{Light-Duty Vehicles}

Private cars are expected to be the transport segment with the higher influence on batteries demand, due to the high absolute number of the global car fleet and the higher size of battery required for cars in comparison with two- and three-wheelers. The current range of battery capacity in available 
electric cars on the market ranges from 15 to $90 \mathrm{kWh}$, depending on the size of the car, its price and the available autonomy.

As of 2018, the global fleet of electric cars reached 5.1 million, with an increase of $63 \%$ on the previous year [8], in line with the year-on-year growth rates of $57 \%$ in 2017 and $60 \%$ in 2016 . This positive trend will likely be strongly slowed in 2020 due to the current situation caused by the global pandemic, but the industry may recover in the next years. Considering the potential evolution by 2030, light-duty vehicles (LDVs), which include passenger cars and small commercial vehicles, may see a share of EVs in their global stock in the range 7-15\%, which correspond to a market share of new EVs that may vary from 15 to $33 \%$. While in the first years battery electric vehicles (BEVs) will represent the largest share, in the longer term a strong increase of plug-in hybrid electric vehicles (PHEVs) is expected, mainly due to their better flexibility in long-range applications [8]. This aspect may directly impact the average battery size of new EVs, since PHEVs have much smaller batteries in comparison with BEVs. This is particularly true in the current models, which are mainly focused on fuel propulsion, with electricity being seen as an integration, but this balance may gradually shift in the future thanks to better battery technologies and a wider availability of the charging network.

The average range of EVs available on the market has continuously increased in the last decade [10], gradually making EVs comparable to traditional cars. Improved ranges mean larger battery sizes, since the efficiency of the engine is already very high. The increase of battery sizes will consequently have an impact on the manufacturing emissions in future electric cars [11], although this effect is expected to be compensated by the increase of the renewable share of the electricity generation. Additionally, the battery sizing is also related to the development of charging networks, as large batteries supported by home charging may help reduce the need of deployment of fast charging systems [12].

\subsection{Other Transport}

While LDVs are expected to be the predominant segment in the transport sector to drive battery demand, other modes that are already facing an increasing penetration of electric applications include buses, two- and three-wheelers and trucks. While two- and three-wheelers show very high numbers in term of units but average limited battery capacity, the opposite is true for buses and trucks.

The stock of electric buses, for which China currently represents $99 \%$ of the global market, showed a $25 \%$ increase in 2018 over the previous year, reaching 460 thousand vehicles [8]. Future outlooks expect a continuous increase of the global fleet electric buses, up to 4.8-8.2 million units by 2030 depending on the scenarios, which would represent $10-15 \%$ of the total bus fleet. Electric buses will be primarily deployed for urban applications, given the more favorable conditions in terms of range and charging infrastructure needs.

Electric two-wheelers are currently well developed in China, with an estimated stock of around 250 million units, which represent over one quarter of the total motorized two-wheelers stock worldwide [8]. However, two thirds of these two-wheelers have a limited performance, with maximum speeds up to $25 \mathrm{~km} / \mathrm{h}$, but the limited batteries (0.5-0.8 $\mathrm{kWh}$ ) and ranges (up to $50 \mathrm{~km}$ ) are acceptable for most urban uses and allow keeping their price competitive with traditional solutions. Other world regions, e.g., Europe, are seeing an increase of shared two-wheelers, while in the private sector their distribution remains low. The global fleet of electric two- and three-wheelers, which currently stands at 300 million units, is expected to increase to $450-560$ million units by 2030, depending on the scenarios.

An additional segment that may see a future increase of electrification is the freight delivery, especially in urban areas. Electric trucks may reach 0.9-3.3 million units by 2030 [8], corresponding to $1-3 \%$ of the total trucks stock worldwide. The electrification of high-duty vehicles is more challenging, especially for long-haul transportation, but deliveries in urban areas will need to face the growing limitation to fossil-based transport technologies in many cities, and, given their limited ranges and speed electric powertrains, they may prove to be an effective solution. The development strategies for 
heavy-duty electric battery vehicles also show a large variability from country to country, with China leading the development of technologies and resources supporting this transport segment [13].

\subsection{Other Sectors}

While the EV sector will likely represent the largest market share of Li-ion batteries, other applications are expected to increase as well, including stationary electricity storage and portable devices. While the latter is somewhat near its saturation, forecasts for stationary storage deployment are significant, due to the necessity of supporting larger shares of variable and unpredictable electricity generation from RES [14].

Stationary storage applications include large-size utility scale storage systems and behind-the-meter applications, which are generally installed by private customers in combination with distributed electricity generation, mostly from PV. Some forecasts on the medium and long term are available in the literature, and they expect a strong increase from the current estimated capacity of 11 GWh worldwide [3].

According to the International Renewable Energy Agency (IRENA) [3], stationary electricity storage deployment could reach up to 421 GWh of cumulative capacity by 2030 in some scenarios, with $56 \%$ of storage represented by behind-the-meter systems coupled with new or retrofitted PV generation plants. Other projections are more conservative, with cumulative capacities in the range 100-181 GWh, with large-scale batteries always representing $44 \%$ of the total capacity.

The most up-to-date projections of the International Energy Agency (IEA), included in the World Energy Outlook 2019 [15], present a cumulative capacity that reaches 560-640 GWh by 2030, and then strongly increases to 1.3-2.2 TWh by 2040, for the Stated Policies Scenario and the Sustainable Development Scenario, respectively. The largest deployments are expected from India, China, the US and Europe.

An even higher forecast is provided by Bloomberg New Energy Finance (BNEF), in the Energy Storage Outlook 2019 [16], reaching 2.85 TWh of cumulative capacity by 2040. According to this forecast, which will require $\$ 662$ billion of investments, the top ten countries will represent three quarters of the total deployed capacity, with China and the US far in front by 2040.

\section{Batteries Supply: Technologies, Manufacturing, Materials}

The supply of Li-ion batteries is currently responsible for a large part of energy consumption and environmental impacts over the batteries life cycle. The battery manufacturing is quickly scaling up to respond to the surge in demand driven by the EV market, and the choices that are being done now will likely shape the Li-ion batteries market in the medium term. Larger factories allow lower costs thanks to economy of scale and standardization of cell production.

This section gives an overview of the complexity of the supply chain, by focusing on the available technologies, the manufacturing assets at global scale, the input materials, some elements on battery costs and safety concerns and the alternative technologies that may prove to be viable solutions in the future.

\subsection{Available Technologies}

High energy density, high Coulombic efficiency and low self-discharge have determined the large success of Li-ion batteries in different applications, such as portable electronics, power tools and, more recently, stationary energy storage and electric vehicles. However, in recent years, different chemistries have been evaluated to obtain the best balance among energy density, cost, safety and reliability, and there is still no single solution that outperforms the others.

The basic element of a battery is the electrochemical cell: it consists of a positive electrode and a negative electrode, electrically and physically isolated by a separator immersed in an electrolyte. During the discharging process, lithium ions diffuse from the negative electrode (the anode) to the positive one (the cathode) while electrons flow through the external circuit. During the charging 
process, lithium ions move back intercalating in the negative electrode. The positive electrode is the element that presents the greatest variability in terms of technological solutions and it represents the main differentiation factor between alternative lithium batteries, whereas the negative electrode is typically made of carbon graphite. In fact, the classification of the Li-ion batteries is based on the elementary composition of the positive electrode; currently, there are five main technologies of lithium batteries: lithium cobalt oxide $\left(\mathrm{LiCoO}_{2}\right.$, abbreviated as $\left.\mathrm{LCO}\right)$, lithium manganese oxide $\left(\mathrm{LiMn}_{2} \mathrm{O}_{4}\right.$, $\mathrm{LMO})$, lithium iron phosphate $(\mathrm{LiFePO}, \mathrm{LFP})$, lithium nickel cobalt aluminium oxide $\left(\mathrm{LiNiCoAlO}{ }_{2}\right.$, $\mathrm{NCA})$ and lithium nickel manganese cobalt oxide ( $\left.\mathrm{LiNiMnCoO}_{2}, \mathrm{NMC}\right)$.

The positive and negative electrodes are electrically connected by the electrolyte. Generally speaking, a good electrolyte should satisfy the following requirements: good ionic conductivity and electronic insulation, wide working electrical potential range, no reactiveness with other cell components, thermal stability, low total cost and low environmental impacts. The main electrolytes employed in Li-batteries can be divided into non-aqueous electrolytes, aqueous solutions, ionic liquids, polymer electrolytes and hybrid electrolytes. The first ones are the most common in commercial application and consist of a lithium salt, such as $\mathrm{LiPF}_{6}$, dissolved in organic carbonates. However, as shown below, the need to develop high capacity batteries has led to the development of other electrolytes which can work under higher voltages such as organic fluoro-compounds. The use of an aqueous electrolyte can reduce safety issues because of their non-flammable property; however, their low cycling performance and reduced operating voltage window limited their success. Recently, ionic liquid electrolytes have shown to be good candidates for the next generation of lithium batteries thanks to their high ionic conductivity, high electrochemical stability and large solubility of organic and inorganic compounds, combined with non-flammable and non-volatile properties. The high viscosity, which limits ionic conductivity, and a relatively larger cost remain the main drawbacks of these electrolytes. In addition, polymer electrolytes show a low conductivity, but they boast mechanical stability and safety, and they reduce lithium dendrite formation. These limits could be overcome by achieving hybrid electrolytes [17].

The separator is the cell element which provides the electronic insulation between the two electrodes, while it allows the ion flow through the electrolyte: its wettability and the contact interface with the electrolyte represent determinant characteristics for the cell performances. An ideal separator should present a high chemical stability, mechanical resistance (without surpassing the $25 \mu \mathrm{m}$ in thickness) and a uniform porosity. There are three main types of separators based on different membrane materials: microporous, nonwoven and ceramic-filled separators. Microporous polypropylene- and polyethylene-based membranes belong to the first category: they typically present good mechanical strength and chemical stability but they are affected by low thermal stability, low pore interconnection and low electrolyte retention. Nonwoven electrolytes show a better ionic conductivity, due to their higher porosity, which, however, compromises the mechanical stability and, therefore, requires specific precautions during the manufacturing process. The dispersion of ceramic particles on the separator membrane improve its thermal stability and conductivity, reducing the probability of hot-spot formation caused, for example, by short circuit. Membrane weight, a decrease in tensile strength and the possibility of particulate shedding during the life of the cell are the main drawbacks which characterize these types of separators [18].

The most relevant characteristics of a battery are its specific energy and power, durability and safety. The specific energy depends on the constituting cathode and anode materials (including their micro-structure) and on the design of the cell (that impacts on the amount of active material contained). The maximum power a Li-ion battery can provide depends on: its voltage, the density of lithium ions, the solid electrolyte interface, the diffusion coefficient of the electrodes and their conductivity. The specific power is typically described by the power-to-energy ratio $(\mathrm{P} / \mathrm{E})$ : the power requirement depends on the application, for instance PHEVs require batteries with a higher power-to-energy ratio than BEVs.

The battery degradation determines the durability of the device and it depends on actual operating conditions, such as operation temperature, overcharging and high amperage. Moreover, Li-ion batteries 
suffer calendar and cycle aging: the first occurs even if the battery is simply stored and not used, whereas the second depends on the charge and discharge conditions and it is due to loss of cyclable lithium and active electrode materials. In general, a battery is considered exhausted when its capacity drops to $80 \%$ of the nominal value. The mix of lithium, oxygen and flammable electrolyte represents the main safety challenge for lithium batteries. A serious concern is thermal runway: if extremely heated, for example due to overcharging or short circuiting, to the level of decomposing the metal oxide, oxygen can react with lithium burning the battery [2]. In Table 1, the main characteristics of the aforementioned types of Li-ion batteries are reported [2,19].

Table 1. Main characteristics of different Li-ion battery technologies.

\begin{tabular}{lrrrl}
\hline Battery & $\begin{array}{c}\text { Energy Density } \\
\mathbf{( W h} / \mathbf{k g})\end{array}$ & $\begin{array}{c}\text { Cyclability } \\
\text { (Cycles) }\end{array}$ & \multicolumn{1}{c}{ Advantages } & Disadvantages \\
\hline LCO & $150-190$ & $500-1000$ & $\begin{array}{l}\text { Technological maturity, } \\
\text { Low-self discharge, } \\
\text { High discharge voltage }\end{array}$ & $\begin{array}{l}\text { High cost, } \\
\text { low inherent safety }\end{array}$ \\
\hline LMO & $100-140$ & $1000-1500$ & $\begin{array}{l}\text { High inherent safety, } \\
\text { Cobalt-free }\end{array}$ & $\begin{array}{l}\text { Low energy density, } \\
\text { Mn dissolution }\end{array}$ \\
\hline LFP & $90-140$ & up to 2000 & High inherent safety & Low energy density \\
\hline NCA & $200-250$ & $1000-1500$ & Low cobalt content & $\begin{array}{l}\text { Capacity fade at } \\
\text { elevated temperature }\end{array}$ \\
\hline NMC & $140-200$ & $1000-2000$ & Low cobalt content & $\begin{array}{l}\text { Safety issues in } \\
\text { Ni-rich batteries }\end{array}$ \\
\hline
\end{tabular}

Although LCO batteries have the highest cobalt content that provides a high-energy density, they are not used in the automotive sector, where NMC and NCA batteries have been more successful because of their lower costs. In fact, NMC (NMC-111 configuration) and NCA present a cobalt mass fraction equal to around $30 \%$ and $14 \%$, respectively [20]. Different car manufacturers have opted for different chemistry solutions, but NMC-cells are the most widely used option (NMC-111 represents $42 \%$ of the EV market share [20]) while only Tesla has preferred to use mainly NCA-cells. According to Avicenne Energy 2018 [21], NMC-cells will represent 70\% of the active material market share in 2025. Due to their lower specific energy, the LFP found more limited application in hybrid, plug-in vehicles and electric buses. However, Tesla has recently shown interest in LFP batteries for use in its electric vehicles: a new battery assembly process, defined as "cell-to-pack", would reduce the amount of material in the battery pack, thus compensating the reduced energy density of LFP chemistry.

In addition to a different chemical composition, lithium cells can vary on geometric configurations. The main solutions are: cylindrical cells, in which electrodes are spiralled into a coil; prismatic cells, which use a rectangular casing; pouch cells, which ditch the hard casing in favor of a lighter and more flexible design, thus reducing the overall weight of the case; and coin cells, mostly used in portable devices.

Cobalt content and maximum capacity values (around $200 \mathrm{mAh} / \mathrm{g}$ ) that conventional lithium-ion batteries can offer have led researchers to focus on different solutions to increase the performance and reduce the demand of cobalt, due to its high cost. Some promising solutions include Li-rich and Ni-rich transition metal oxide and high-voltage Li-ion batteries.

The major advantage of the Li-rich layered transition metal oxide batteries are the superior theoretical capacity $(>250 \mathrm{mAh} / \mathrm{g})$ with high chemical potential $(>4.6 \mathrm{~V} \mathrm{vs}$. $\mathrm{Li}+/ \mathrm{Li})$, high discharge capacity, good thermal stability and lower cost compared to the traditional batteries. These high-energy density batteries, however, suffer from irreversible capacity loss during the initial cycle. Voltage decay on further cycling is another major drawback of this battery system [22].

Recent developments in the field of EVs have led to a renewed interest in NMC cathodes with higher nickel concentrations: the increase in nickel concentration leads to higher charge capacity but 
the high voltage required for the charge leads to electrolyte decomposition and also to phase transition of $\mathrm{NiO}$ from a layered phase into a spinel-like and/or salt-like phase. Additionally, one major problem of high voltage cathode $(4.5-5.0 \mathrm{~V})$ is the severe decomposition of the electrolyte, as the conventional carbonate-based electrolyte become unstable in the voltage range higher than $4.4 \mathrm{~V}$ [22].

\subsection{Manufacturing Assets}

According to BloombergNEF, in early 2019, the global lithium cell manufacturing capacity was around $316 \mathrm{GWh}$, with $73 \%$ of this capacity located in China [23]. Generally speaking, the lithium cell market is dominated by only three countries, namely China, Japan and South Korea, while a handful of companies dominates the market, namely Samsung SDI, LG Chem, Sanyo-Panasonic, Sony, BYD and others [24].

Global capacity is projected to grow robustly in the near future: 1211 GWh by 2025 is forecasted by BloombergNFE, whereas Avicenne Energy forecasts $1200 \mathrm{GWh}$ of Li-ion battery sold in 2030 . In particular, the Chinese and non-Chinese electric mobility sector will cover, respectively, $38 \%$ and $47 \%$ of the entire market share [23,25]. According to BMI, by 2028 , more than $72 \%$ of lithium ion capacity production will be located in Asia (65.2\% China, 3.8\% Japan and 3.3\% South Korea) while Europe and US will represent, respectively, $17.2 \%$ and $10.2 \%$ of global capacity [26].

The development of electric mobility and the new business opportunities that are being created have led numerous players to invest in the lithium battery market. Each of those has developed a different business strategy in order to optimize profit margins or reduce supply chain risks. Players that traditionally operate in the battery manufacturing, such as Ningbo Shanshan, Toyota Tsusho and Great Wall Motors, have shown an increasing interest for investments in upstream mineral extraction and processing. This vertical integration along the battery value chain aims to reduce the exposure to commodity price volatility, to sustain the incremental demand of raw materials and to improve channel to market. An example is represented by Lithium Australia, whose operations cover the whole lithium supply chain, from mining to recycling spent batteries [27].

Other players moved outside their comfort zone adding battery investments to their traditional business such as Total, which acquired battery manufacturer Saft; Dyson, which bought Sakti3; and Daimler, which developed an investment plan of $\$ 1.1$ billion in the battery market for the next five year [28].

Different car manufacturers adopted different strategies on battery pack manufacturing. Japanese and Chinese OEMs typically maintain a higher control on all steps up to the segment of the cell and battery pack manufacturing process. European OEMs are endeavouring to maintain design and pack assembly in Europe, because of the absence of significant domestic cell manufacturing capacity. In Japan, Lithium Energy Japan supplies the full battery pack of the Mitsubishi Outlander PHEV. Lithium Energy Japan is a joint venture between GS Yuasa, Mitsubishi Corporation and Mitsubishi Motors Corporation. Automotive Energy Supply Corporation, jointly owned by Nissan and the Japanese electronics firm NEC, provides battery pack for the Nissan Leaf. In the US, Tesla and GM are the two main OEMs active in the EV business. They are developing two opposite strategies. While historically Tesla assembled its battery packs using cells supplied by Panasonic, with the building of its giga-factory in Nevada, it started to produce its own lithium cells. GM chooses to outsource its entire cell and pack manufacturing including the battery management system [24].

\subsection{Input Materials}

The manufacturing of Li-ion batteries require multiple input materials, including lithium, cobalt, nickel and graphite. Strong variations of demand may have an impact on short-term availability, and proper assessments are required [29]. In addition, some input metals are currently produced in specific world regions and countries, and this could lead to possible future geopolitical concerns, which are discussed in Section 6. 


\subsubsection{Lithium}

Lithium is involved in ceramics, glasses, greases and polymer production as well as in technological advanced sectors such as pharmaceutical and nuclear ones. However, it is the battery sector that saw the main expansion on lithium demand, driven by the development of the consumer electronics since 1990s and, more recently, by the automotive sector. In fact, its low density $\left(0.534 \mathrm{~g} / \mathrm{cm}^{3}\right)$ and very high electrochemical potential ( $-3.045 \mathrm{~V}$ versus standard hydrogen electrode) make lithium a crucial element for electrochemical applications.

According to USGS 2020 [30], global end-use of lithium is divided into: $65 \%$ batteries, $18 \%$ ceramics and glass, $5 \%$ lubricating greases, $3 \%$ polymer production, $3 \%$ continuous casting mold flux powders, $1 \%$ air treatment and $5 \%$ other use. In 2015 , the same source estimates that only the $31 \%$ of lithium production was employed in the battery sector.

This market expansion imposed a significant pressure on supply side, which resulted in efforts on exploration and production of new resources, as evidenced by the evolution on estimations of global reserves and resources. Considering USGS data, reserves estimated in 2020 almost doubled compared to those published ten years ago: nowadays, global reserves of lithium are estimated at 17 million $\mathrm{t}$.

Because of its high reactivity lithium does not occur free in nature but in mineral form. The main deposit of lithium are brines, ores, clays and sea water: to date, only the first two are economically available for lithium exploitation and only a few lithium projects have the capacity and ability to produce very high-grade lithium compounds that batteries need [31].

Most brine deposits are located in South America, in particular in the region known as the "lithium triangle", a territory straddling Argentina, Chile and Bolivia that includes, respectively, in these states, the Salar de Hombre Muerto, the Salar de Atacama and the Salar de Uyuni, the largest known lithium deposit. Including China, $70 \%$ of global lithium brine resources are located in just these four countries. Salt lake brines are water resources with high concentration of mineral salts, including lithium, even though its concentration is low $(0.017-0.15 \%)$ and very variable between different salars. Lithium is produced by the evaporation process of the brines, which are pumped to the surface in huge pools. The evaporation process can take about 12-18 months, depending on weather conditions (e.g., solar irradiation and wind speed) and on concentration of other minerals (such as magnesium) [32,33]. This makes these plants not very flexible and able to adapt the production to fluctuations in prices and market conditions [34]. Because of the low lithium concentration in brines, large volumes of groundwater have to be extracted and evaporated. The brine is usually not suitable for irrigation or as drinking water, but, interfering with the water balance of the geological structure can cause the decline of fresh water outside the salt lake. The estimates of the amount of consumed water go up to two million liter of water for one ton of lithium. Brines can also be extracted from geothermal and oilfield brines, even if not in large scale.

Ore lithium is found in more than 154 different minerals, but it is extracted only from spondumene (the most abundant lithium ore), lepidolite, petalite, amblygonite and eucriptite, typically contained in igneous rocks named pegmatites. The greatest lithium ore deposit, the Greenbushes mine, is located in Australia, the world's largest producer; however, other deposits can be found in the US, China, Zimbabwe, Russia, Canada and Europe (Germany, Czech Republic and Serbia). Petalite is commonly used for glass manufacture due to its high iron content, while lepidolite lost his importance as lithium resource because of high fluorine content. Compared to brine lithium, ore lithium is characterized by greater operating cost due to mining, grinding and thermal treatment steps, but the production process is more stable during the year and can vary more easily to meet market needs. Even if the largest pegmatite deposits have estimated resources comparable to an average brine deposit (about $76 \%$ of global lithium reserves are brine-based deposits), their wider geographic distribution and their more flexible response to market changes ensure that pegmatite will remain of interest in the future $[35,36]$. A more exhaustive review on exploitation techniques of brine and ore lithium goes beyond the aim of this work, but additional information is available the works of Choubey et al. [37] and Flexer et al. [38]. 
In total, 230 billion $\mathrm{t}$ of lithium reserves are estimated to be present in sea water. Of course, this non-conventional resource of lithium is not limited to a geographic boundary but the low lithium concentration in sea water $(0.1-0.2 \mathrm{ppm})$ makes the recovery process very complicated and expensive. In addition to conventional adsorption processes, Choubey et al. reviewed new extraction techniques such as the diffusion-dialysis process. The commercial viability of this unconventional sources is linked to the potential rise in price of lithium [39].

Only four companies dominate primary lithium production: Talison Lithium (Australia) 39.8\%, SQM (Chile) 22\%, Albemarle (US) 16.2\% and FMC (US) 9.7\%. Moreover, with the recent acquisition of a $24 \%$ share in SQM, Tianqi (China) has acquired an increasing role in the sector. The same company holds a 50\% stake in Talison's Greenbushes mine as well [40,41].

Lower production costs compared with the mining and processing costs of hard-rock ores allowed subsurface brines to become the dominant raw material for the lithium carbonate production in the late 1990s. Nevertheless, mineral-sourced lithium regained market share and was estimated to account for one-half of the world's lithium supply in 2015, because of the increase of lithium demand from China in the past years [42].

Figure 2 reports the evolution of lithium mining in the first four countries worldwide in the last years. These four countries represent roughly $95 \%$ of the global production, excluding the production in the US, for which data are not available due to private company proprietary data. A significant increase is noticeable in the last years, especially due to the Australian spondumene operations, which ramped up production in 2017, becoming today the world's largest lithium producer [30].

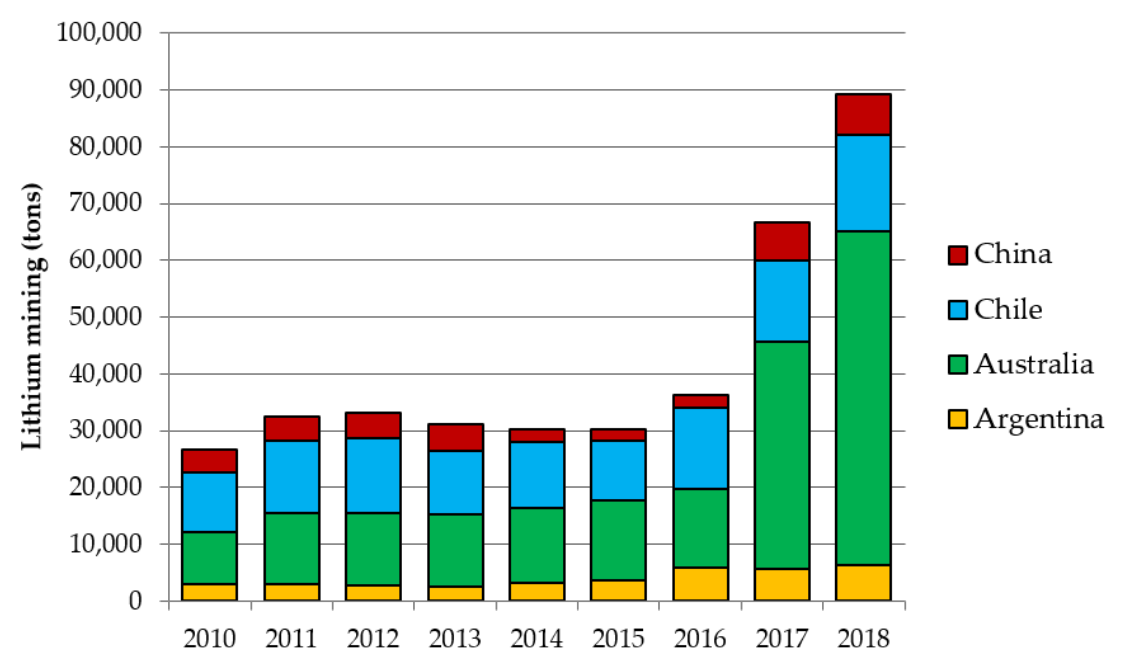

Figure 2. Production of lithium from mining in the first four countries. The authors' elaboration on [30].

Lithium is not produced in its metallic form but as basic chemicals, namely lithium carbonate, lithium hydroxide, lithium concentrate and lithium chloride. These lithium chemicals are employed in a wide range of applications such as glasses and ceramics for lithium concentrate and lubricating greases for lithium hydroxide. Lithium carbonate is the typical form used for battery applications and represented $46 \%$ of the market in 2015 ; lithium hydroxide is becoming increasingly important (19\% of the market in the same year) due to the development of low cobalt grade lithium batteries [43]. Metallic lithium is used only in a limited number of applications, such as in the pharmaceutical sector. In the chemical production stage, China has the highest production capacity ( $40.7 \mathrm{kt}$ LCE lithium carbonate, and $20.5 \mathrm{kt}$ LCE lithium hydroxide in), followed by Chile and Argentina. The main lithium trades are from Chile and Australia to China, which also imports lithium concentrate from Australia [44,45].

It is now widely accepted that world's lithium reserves are adequate to support the expected growth of the electric vehicle industry: the point is that temporary supply shortages might occur, driven by a potential drastic increase of lithium demand within the short term. Asian technology 
companies' top priority has become lithium supply security. Strategic alliances and joint ventures have been, and are continuing to be, established with lithium exploration companies to ensure a reliable, diversified supply of lithium for Asia's battery suppliers and vehicle manufacturers [30].

\subsubsection{Cobalt}

Long considered a poor quality metal, the "goblin ore" (as German miners used to name cobalt) plays, in our society, important roles in various technical applications such as superalloys, magnets, catalysts and rechargeable batteries. In 2015, around $49 \%$ of global refined cobalt demand derived from the battery sector, including Li-ion batteries [20].

Cobalt is not a rare element even though it is found only in mineral form in nature. In fact, cobalt occurs with other elements in such minerals as carrollite (a sulfide of copper), skutterudite (a cobalt-nickel arsenide) and asbolane (a nickel-cobalt manganese oxide). In addition to the cobalt mines of Bou-Azzer (Morocco) and Mukondo (DRC), it is produced as a byproduct of copper and nickel ore extraction. Cobalt is mainly extracted from three main types of mineral deposits: sediment-hosted stratiform copper deposits, such as in the Copperbelt (a Central Africa region between the Democratic Republic of Congo and Zambia); magmatic nickel sulfide deposits, such as those in Canada and Russia; and nickel laterite deposits, such as those in New Caledonia. Moreover manganese nodules and crusts on the deep seafloor represent unexploited cobalt deposits, due to technical and economical reasons [46]. From the 7 million $t$ of global reserves, $50 \%$ are located in DRC, followed by Australia with a share of $17 \%$ [35].

Nowadays, the DRC continued to be the world's largest producer of cobalt, supplying about $70 \%$ of global production, while China is the world's leading producer of refined cobalt, accounting for $46 \%$ of global production; more than $80 \%$ of its production is used by the rechargeable battery industry [30]. To reduce the supply risk exposure of its refinery industry, the Chinese government has promoted investments in foreign mining activity, in particular in the DRC where Chinese companies together accounted for $24 \%$ of total mine production in 2016. As a result, China has come to control around $29 \%$ of its net import of cobalt and intermediate materials [47]. Around $23 \%$ of global refined capacity is installed in Europe, mainly in Finland [35]. Few companies dominate the global production: Glencore, mainly operative in Katanga (Southern DRC), is the main cobalt producer, followed by China Molybdenum, Fleurette Group, Vale and state-owned Gécamines. Therefore, the global supply chain turns out to be very concentrated and potential bottlenecks can arise, linked to the political and economical dynamics of these two countries: in particular, since 2017, the instability of the DRC, combined with the soaring demand for batteries for transport, appears to have pushed prices up [20]. Since 2000, cobalt demand has begun to rise progressively driven by the rechargeable battery development, initially used in electronic equipment and nowadays in electric vehicles as well: according to WMD 2018 cobalt mine production has increased by around $270 \%$, from 34,000 $\mathrm{t}$ in 2000 to around $126,000 \mathrm{t}$ in 2016 . However, as a byproduct of large-scale copper and nickel operations (respectively, $43 \%$ and $47 \%$ of global production), cobalt production is linked to the market dynamics of these two commodities: their prices can affect the amount of cobalt that is recovered from these sources [48]. An additional 11\% of production comes from artisanal and small-scale miners (ASM) mainly in cobalt-copper deposits in DRC. Around $20 \%$ of production in DRC is the result of child labor in the ASM, representing the biggest social challenge for the cobalt supply chain: automotive and IT industries have come under strong public pressure to ensure that their supply chain is free of child labor [35].

\subsubsection{Others}

Historically, the demand of nickel has been driven mainly by the production of stainless steel. Although both Class 1 nickel (metallic form) and Class 2 nickel (form of alloys or chemical compounds) have found application in the sector, with the emergence of Chinese steel production, it was the latter type of nickel that took the windward, due to its lower production costs. This led to the closure of many of the related production mines. Class 1 nickel is in fact characterized by a higher level of purity, 
greater than $99.8 \%$, and it is the nickel of current use in the electrochemical sector, in the form of nickel sulfate. The production of nickel sulfate from Class 2 nickel is currently economically prohibitive. The emerging electric vehicle industry could represent a new positive period for nickel producers. Of the approximately 300-350 kt of nickel sulfate produced in 2017, about half was destined for the production of batteries. As of 2025, the demand for nickel by the electrochemical sector could increase tenfold compared to the current one, but these projections are strongly influenced by the technological choices of battery manufacturers. An extreme scarcity of cobalt could in fact lead to the affirmation of technologies such as LFP, which is lacking the aforementioned material as well as nickel $[49,50]$.

Although only a small part of global graphite production was used for lithium batteries in 2016, the supply of high purity electrochemical graphite (flake graphite) can present some critical issues. During 2019, China produced more than $60 \%$ of the world's graphite; of the Chinese production, about $60 \%$ was flake. Although the United States do not have mines currently operating, they are starting the development of two mines in Alabama and Alaska. Large graphite deposits were being developed in Madagascar, Mozambique, Namibia and Tanzania. Some mines in Madagascar and one in Mozambique, which is the world's largest natural graphite mine, started to ramp up production since 2018. This led to an oversupply that decreased graphite prices to the level of 2017. To stabilize prices, some mining companies started to cut back production. From recycling processes, such as from refractory materials, it is often not possible to recover high quality graphite to be used in batteries. However, it is possible to produce graphite on an industrial level starting from amorphous carbon, by means of high temperature processes. However, due to the high energy consumption, synthetic graphite is up to 10 times more expensive than its natural equivalent [30].

Additionally, Ballinger et al. [51] underlined the potential issues related to the supply of rare-earth elements for Li-ion batteries production in strong decarbonization scenarios, due to the very high penetration of EVs. They underlined the need of incorporating these risks in future modeling scenarios.

To date, lithium battery electrolyte is not subjected to particular resource constraints. It is typically composed by a Li salt, such as dissolved in an organic solvent that combine a linear and a cyclic carbonate, such as ethylene carbonate and dimethyl carbonate. In addition, the electrolyte market is dominated by Asian companies (China 60\%, Japan 18\% and South Korea 14\%) but in 2015 most of these companies operated at less than half of their capacity while most European and American companies operated at less than $10 \%[24,52]$.

\subsection{Other Aspects-Safety and Cost}

Two additional aspects should be considered when discussing battery supply chain, since they both have an effect on different design and manufacturing choices: safety and cost. While decreasing costs through performance improvement and manufacturing upscale are at the basis of a wide deployment of EVs, the guarantee of high safety standards is of paramount importance for the adoption of this technology.

The maturity of Li-ion batteries, thanks to their continuous development in the last decades, ensures a high level of safety and reliability, and currently heat related failures are relatively rare. Cells manufacturing often requires a compromise between energy density and safety, and additional measures are included to avoid cell overheating through excessive currents. In comparison with the applications for portable electronics, Li-ion batteries for EVs involve additional complexity which affect safety aspects, due to the fact that a large number of cells is connected in series and in parallel. Due to the variable real-life conditions of EVs, batteries face a wide range of temperatures, frequent vibrations, potential crashes and fast charging. A detailed review of different safety aspects for Li-ion batteries applied to EVs was reported by Duan et al. [53]. In addition, Gandoman et al. [54] presented an extensive review of all the different aspects that are involved with reliability and safety of Li-ion battery operation, with a detailed description of all the possible failures and the existing standards.

Battery costs, which are usually expressed as specific costs based on the energy storage capacity, are often provided at battery cell level or at battery pack level. The literature provides different 
estimates of battery costs evolution, with a strong decrease of average costs in the last decade [55] that is expected to continue in the future. Some more detailed research works provide cost models that include different parameters, such as the technology, the variability of the cost of metals as well as the role of upscaling [56]. However, as mentioned above, it is important to be aware that since many parameters affect these figures, the dynamics behind manufacturing costs are constantly evolving, and each scenario of future cost is related to multiple assumptions. Moreover, many assumptions are often limited by the unavailability of reliable and updated data from actual manufacturing sites, especially when dealing with commercial and industrial confidentiality issues.

\subsection{Future Alternative Technologies}

Given the time period needed by $R \& D$ improvements in order to be implemented in large scale production plants of lithium batteries, the current chemistries are expected to remain which of principal use for around the next ten years [57]. Exhaustive reviews of next generation lithium batteries were presented by Kim et al. [22], Nitta et al. [58] and Zubi et al. [2].

The next generation Li-S battery offers a very high theoretical capacity $(1675 \mathrm{mAh} / \mathrm{g})$ and a competitive advantage derived from the abundance of sulfur (compared to cobalt and nickel). However, there are some technical barriers that prevent mass commercialization of Li-S batteries. In fact, they suffer of low electrochemical potential, low electrical conductivity and sulfur electrode expansion of around $80 \%$ during Li-ion intercalation, causing material cracking and detachment from the electrode conductive network. Furthermore, intermediate reaction processes formed during charge and discharge are soluble in the electrolyte, causing the shuttle mechanism, responsible for self-discharge, overall poor Coulombic efficiency and capacity loss.

Owing to their theoretical energy density of $3500 \mathrm{Wh} / \mathrm{kg}$, lithium-air batteries represent another attractive high-capacity lithium battery technology. Typically, the anode is a lithium metal, while the cathode is a carbon matrix with a catalyst. The electrolyte can present in four different forms: aprotic, aqueous, mixed and solid. The reduction process of the oxygen provides an electromotive force of $2.9 \mathrm{~V}$. The use of ambient air can lead to a series of reactions due to the presence of $\mathrm{N}_{2}, \mathrm{CO}_{2}$ and $\mathrm{H}_{2} \mathrm{O}$ that reduce the reversibility of the electrochemical performance. The oxygen electrode requires high electronic and ionic conductivity, electrochemical stability, fast oxygen diffusivity, porous structure and high activity for oxygen reactions. All carbonaceous electrode materials can notably degrade by the interaction with superoxide and peroxide moieties and, therefore, non-carbonic oxygen electrodes have been of great interest [22].

Li-ion batteries that use organic material as electrolyte drawn attention because of their sustainability and abundance of organic elements, but they are characterized by low-energy density, poor conductivity, poor reaction kinetics and high solubility in electrolyte.

The main distinctive element of solid-state batteries is the solid electrolyte that can occur in three main different forms: inorganic, polymeric and thin-film. Among inorganic electrolyte, oxide-type have received great interest for its high chemical stability, excellent mechanical properties and good safety and conductivity. On the other side, its non-flexibility and high-cost for scale-up productions have hindered its commercialization. Sulfide-type solid-electrolyte presents a higher electrical conductivity but its low oxidation stability and poor compatibility with electrodes represent major drawbacks. Polymeric solid-electrolytes present good flexibility, high stability with Li-metal and low shear modulus but also low thermal stability, low ionic conductivity and low oxidation chemical potential. Thin-film solid electrolytes represent the key element for the development of thin-film batteries, that drawn attention for their higher energy density, flexibility in application design and compactness compared to conventional Li-ion batteries [22].

Solid state lithium metal polymer (LMP) batteries show promising performance for both stationary storage and EVs. In addition to a better safety and higher energy density in comparison with Li-ion batteries, they may also provide some advantages in terms of emission savings in the manufacturing [59]. However, their technology readiness level is still low, and their higher costs are currently hindering a 
wide adoption. Solid state batteries costs are expected to remain in the range $\$ 400-800 / \mathrm{kWh}$ by 2026 , and they will eventually see a limited market share in luxury or upper-level cars [60].

Liu et al. [61] first demonstrated a secondary $\mathrm{Li} / \mathrm{CO}_{2}$ battery, although a previous primary $\mathrm{Li} / \mathrm{CO}_{2}-\mathrm{O}_{2}$ battery was introduced by Takechi et al. in 2011 [62]: this battery presented a discharge capacity three times greater than $\mathrm{Li}$-air batteries. The reversibility of the $\mathrm{Li} / \mathrm{CO}_{2}$ battery is guaranteed by $\mathrm{Li}_{2} \mathrm{CO}_{3}$, which is however an insulator and requires a high oxidation potential during charging. The high over-potential and the low Coulombic efficiency represent the main obstacles to the diffusion of this technology.

\section{End-of-Life: Challenges and Opportunities for Batteries Recycling}

Battery manufacturing is responsible for a large part of energy consumption and GHG emissions over battery lifetime, but the role of end-of-life should not be forgotten. While currently this sector needs to be further developed, the possibility of recovering materials from depleted batteries could prove to be a useful solution to the issues related to input materials supply chains. Battery recycling solutions should evolve in parallel with the current upscaling of their manufacturing, to be ready to face the huge volumes of batteries that will reach their technical lifetime in the next years.

Energy storage in EVs needs to guarantee high levels of performance, and they are generally suitable for operation as long as they ensure at least $80 \%$ of their nominal capacity, which is a threshold that is commonly accepted in the literature. However, in a research work based on the statistical analysis of several EVs charging profiles, Casals et al. [63] highlighted that $80 \%$ of state-of-health for EVs batteries is a good threshold for smaller cars (with batteries up to $16 \mathrm{kWh}$ ), while larger cars may extend the battery life to $70 \%$ or $60 \%$ in some cases. These results suggest that larger batteries in future EV applications may be better exploited and allow longer mileages, but at the same time it is important to remember that in this case their potential for second-life applications will be strongly reduced. Thus, coherent evaluations will be needed to take into account the benefits and the impacts considering a wider perspective on the entire battery cycle, from manufacturing to end-of-life.

Nevertheless, considering the current standard threshold of $80 \%$ of nominal capacity, Li-ion batteries that are no longer suitable for EVs applications may face three alternative pathways: remanufacturing, repurposing and recycling [64].

The idea of remanufacturing a battery is based on the fact that usually the performance degradation is not evenly distributed across all the cells of the battery, but it may involve only a limited part of cells. By properly locating the affected cells and removing them from the battery pack, it is possible to refurbish the battery and make it available for further applications in the EV sector. Advanced screening methods may be used to properly evaluate the aging of cells [65] or to estimate the remaining useful life of the battery [66]. In this case, it is necessary that the resulting product can fulfill all the requirements for these applications.

The second option, repurposing, is based on the idea that a performance lower than $80 \%$ is not an option for EVs applications, but it may be suitable for alternative applications, especially for stationary storage (for either large or small applications). In particular, the lower price of the battery may represent a strong incentive for these applications [67]. In addition to replacing damaged cells or modules, often repurposing includes reconfiguring the modules or packs, including a new battery management systems (BMSs), to match the requirements of the specific application.

These first two options increase the lifetime of the battery, and thus they should be supported to increase the usage of the battery and lower the associated environmental impact for unit of energy supplied. The final option, recycling, can be used to recover as much material as possible from the depleted battery. Unfortunately, the large variability in material chemistries in current applications results in a significant challenge for the standardization and upscaling of recycling procedures [64]. In addition to the variable use of materials within the cells, the architectures of modules and packs vary across manufacturers, and they also show variations over time. Moreover, many current business models are based on the recovery of cobalt [68], which is a high-value mineral, but for this very same 
reason battery manufacturers are trying to shift towards solutions with lower shares of cobalt and higher shares of nickel. Thus, the economic profitability of future recycling solution may become even lower.

Li-ion battery recycling could follow the existing know-how of other battery recycling pathways, such as lead-acid and NiMH batteries, which have shown high level of recycling rates. Critical aspects are an effective collection rate of depleted batteries and, given the variability of chemistries, the possibility of reaching suitable amounts of batteries of the same type (and in particular with the same cathodes).

Currently, three main technologies exist for the recycling of Li-ion batteries materials: (1) pyrometallurgy; (2) hydrometallurgy; and (3) direct recycling. The first two options are already mature technologies that are starting to operate at industrial scale. The third is still at lab/pilot scale [64], while and other methods are still at early stage of research, and in some cases they show promising efficiency, although they are often focused on very specific chemistries [69].

There are different industrial facilities around the world, but they are mostly concentrated in few countries in North America, Europe and some Asian countries (China, South Korea and Japan), which will require dedicated collection and transport solutions for depleted batteries. A crucial role will be played by national regulations, which will need to provide specific requirements for $\mathrm{Li}$-ion batteries recycling to support an effective industrial development in the sector.

\section{Environmental Impacts}

As previously discussed, the production chain of lithium batteries is quite complex: the production of a battery requires around twenty different materials, which require multiple stages of refining, some of which are specifically designed for applications in the electrochemical field [70]. Different production steps (extraction, refining, cell production, etc.) take place in different locations and, therefore, the choice of the energy mix is crucial for the results of the environmental analysis, in particular for energy intensive processes [71]. For example, according to Hao et al. [72], electricity use accounts for around $40 \%$ of all greenhouse gases (GHG) emissions of the manufacturing process. In their study, it results that GHG emissions of Chinese LFP, NMC and LMO batteries are, respectively, 3, 2.8 and 2.9 times greater than those of their American counterparts. More precisely, the LFP, NMC and LMO battery GHC emissions from the production of a 28-kWh battery are, respectively, 3061, 2912 and $2705 \mathrm{kgCO}_{2 \mathrm{eq}}$. These results imply around 30\% increase in GHG emissions from vehicle production compared with conventional vehicles. It is worth noting that, to obtain the same final product, different chemical processes can be used and that the transport of raw materials and intermediates can take place by different solutions. These elements also contribute to different energy consumptions.

Moreover, the variability of cathode solutions, cell and battery pack configurations has a strong impact on the total carbon footprint of lithium batteries. Ciez et al. [73] showed how, for the same considered energy mix, different chemistries and battery configuration correspond to different GHG emissions: for the same chemistry, pouch configuration shows a lower GHG emission than the cylindrical one and, among these, a pouch-NMC presents the lowest average emission $\left(36 \mathrm{kgCO}_{2 \mathrm{eq}} / \mathrm{kWh}\right)$, whereas the cyclindrical-NCA the highest $\left(49 \mathrm{kgCO}_{2 \mathrm{eq}} / \mathrm{kWh}\right)$.

Of the countless publications that deal with the environmental impacts of lithium batteries, some are now dated, referring to a production context that is very different from what the current market situation is. Furthermore, very few refer to data obtained in situ, also due to the difficulty of finding data in industrial contexts, and, therefore, they use models to estimate them. Peter et al. [74] highlighted how the majority of the reviewed studies do not provide own original inventory data and only few studies are taken as data sources for the others.

Of the three main components that make up the battery pack-the cell, the BMS (battery management system) and the pack itself (i.e., the structure that contains the various components)-the cell is the one that requires the greatest amount of energy for its entire construction process. In fact, its assembly is preceded by the processes of extraction and preparation of different chemical elements. In [75] is pointed out as energy use (e.g., diesel or electricity) in different mines can vary depending of type of mine and ore. However, the largest energy consumption is associated with the manufacturing 
process of the electrochemical cell: in fact, its assembly requires a dehumidified environment and the drying of the cell before sealing.

A representation of the $\mathrm{CO}_{2 \mathrm{eq}}$ emission levels associated with the production of lithium cells is shown in Figure 3, which is based on data collected in different publications over the last decade [71-73,76-84]. The publications have been colored by years, and, despite the significant variability within each group, a decreasing trend is noticeable, especially in the last years. New data come from more precise plant analyses and they refer to commercial-scale factories instead of pilot-scale factories, which operate at higher efficiency levels [71]. The variability of the results depends not only on the mix of power generation sources that is considered in the manufacturing phase, but also on the technologies that are being analyzed (LMO, NCM, NCA and LFP). While the limited amount of data does not allow drawing statistically significant analyses, this chart provides a descriptive comparison of different literature results.

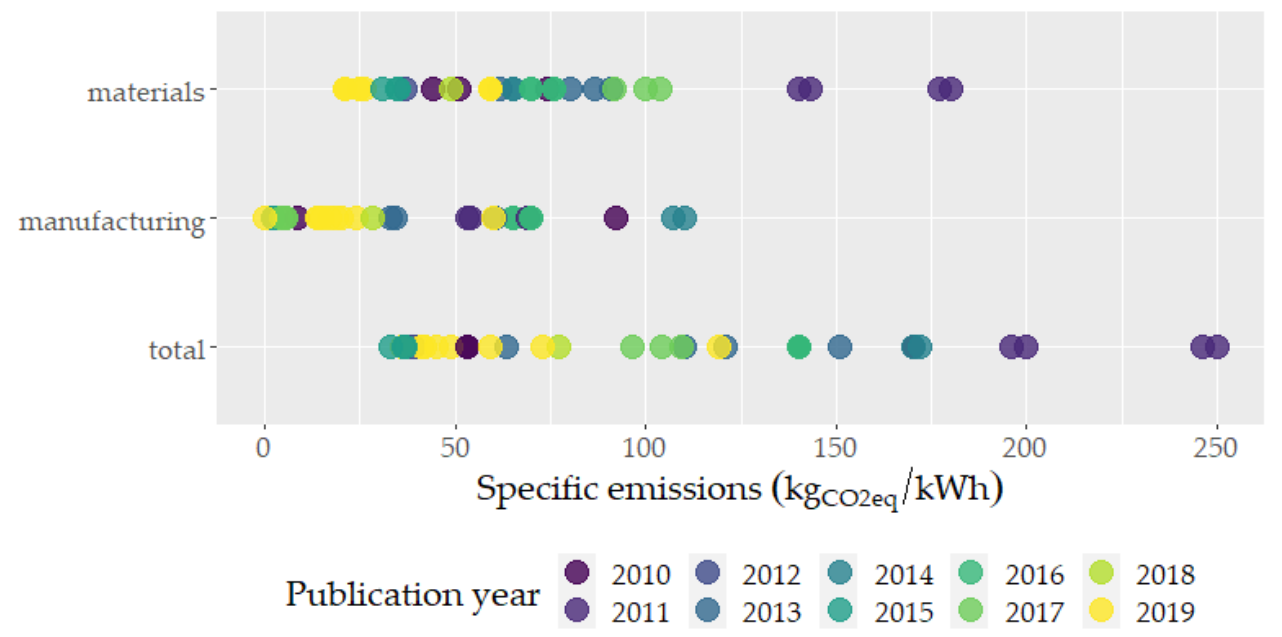

Figure 3. Specific emissions related to Li-ion cells production. The authors' elaboration on [71-73,76-84].

The importance of the upstream phases of input materials is confirmed by Jiang et al. [85], who underlined the need of accurate information on the actual upstream process to obtain reliable LCA results for Li-ion batteries. They highlighted the higher impact associated to rock lithium in comparison with brine-based lithium, in particular due to the leaching process. The largest differences across the various impact categories were found in global warming and acidification effects.

Additionally, when comparing LCA studies, it is also important to be aware of the different parameters and hypotheses that are necessary to draw meaningful indicators. While the Li-ion battery manufacturing is generally focusing on the impacts referred to the battery capacity, when considering real applications, it may be more useful to estimate the impact related to the useful energy delivered by the batteries. Here, the hypotheses on the lifetime and cycling behavior are of paramount importance. A comparison of different chemistries for residential storage application pointed out that the total environmental impact depends more on cycling frequency than chemistry choice, and there is no significant difference across battery chemistries [86]. A similar study on EVs pointed out the importance of addressing real-life operational conditions and battery capacity fade [87]. Moreover, the relative importance of the manufacturing phase and the use phase is often dependent on the electricity mixes of the countries where these two phases take place. Generation mix may also show strong variations within countries, across hours or months depending on available sources, but also over the lifetime of batteries due to the evolution of generation assets in different countries.

As mentioned in the previous section, battery recycling offers the possibility of reducing $\mathrm{CO}_{2 \mathrm{eq}}$ emissions by making already extracted materials available for the construction of new batteries. Obviously this remains true if, ceteris paribus, the energy consumption associated with recycling is lower than that associated with virgin materials processes. In that regard, in addition to the type of lithium battery technology, the recycling process considered is crucial. Several studies show how direct 
and hydrometallurgical recycling are the best options in this regard. Pyrometallurgical recycling is often disadvantageous, in terms of emissions, compared to the production of new virgin materials. Ciez et al. [73] estimated the emissions in terms of $\mathrm{CO}_{2 \text { eq }}$ deriving from the construction and recycling of the battery pack. They examined different technologies of lithium batteries and different recycling processes, evaluating the offset resulting from material recycling. Three common cathode chemistries are taken in consideration: lithium nickel manganese cobalt oxide (NMC-622), lithium nickel cobalt aluminium oxide and lithium iron phosphate. The analysis shows that the extraction of ferrous elements used in LFPs is much more energy efficient and less emissive in terms of $\mathrm{CO}_{2 \mathrm{eq}} / \mathrm{kWh}$ than elements such as nickel, cobalt and manganese, making recycling non-positive in terms of $\mathrm{CO}_{2 \text { eq }}$ saved. The reduction of $\mathrm{CO}_{2 \mathrm{eq}}$ emissions is more relevant in the case of direct recycling of NMC and NCA in the punch configuration and in the case of hydrometallurgical recycling for cylindrical NMC cells. The average emissions associated with a battery pack production process is about $41.6 \mathrm{kgCO}_{2 \mathrm{eq}} / \mathrm{kWh}$.

Nevertheless, when considering emissions associated to battery recycling, it is important to avoid double counting, by allocating them to the new battery that is being manufactured instead of including them also in the end-of-life of the depleted battery.

While the majority of studies underline the impacts related to global warming, it is important to remember that the production of Li-ion batteries involves other environmental impacts, including fossil and mineral resources depletion; ozone layer depletion; eutrophication and acidification of freshwater and marine water; and water and terrestrial ecotoxicity [59]. While most LCA studies address all these impacts, the available literature seems to be rather focused on GHG emissions, which is usually the main outcome of such analyses and the primary indicator to compare the use of batteries with alternative technological solutions in different domains.

\section{Applications in Transport}

The GHG emissions related to the battery manufacturing have been presented with reference to the energy storage capacity, which allows a comparison between different sizes and technologies. However, it is important to remember that, in addition to a comparison between battery technologies, the application of Li-ion batteries to the transport sector requires a comparison with existing technologies. Thus, battery production should also be considered in a wider perspective, as it often represents one of the largest shares of LCA emissions for an EV.

When considering the average emissions related to the life cycle of a vehicle, the comparison is often performed on the basis of each travelled kilometer over its lifetime. For this reason, any LCA study is based on multiple parameters, including the vehicle performance, its average annual mileage, the duration of the battery, the charge-discharge cycles, etc. Some of these aspects are based on design choices, while others are strictly related on the behaviour of the users, or on the type of sources that are used to generate the electricity supplied for charging EVs. Current studies rely on average values that vary from country to country, but generally confirms that, in terms of GHG emissions, EVs are already often performing better than traditional cars relying on oil products.

A recent study based on different EU countries [88] shows that the lifetime emissions of new EVs allows GHG emission savings between $29 \%$ and $79 \%$ in comparison with diesel and gasoline cars, depending on the country. The average savings at the EU level reaches $63 \%$, with average emissions of a new electric medium car standing at $90 \mathrm{~g}_{\mathrm{CO} 2} / \mathrm{km}$, of which $22 \%$ is related to the battery manufacturing. Different electricity mixes in battery manufacturing may shift emissions up to $99 \mathrm{~g}_{\mathrm{CO}} / \mathrm{km}$ or down to $86 \mathrm{~g}_{\mathrm{CO} 2} / \mathrm{km}$, with respective shares of battery manufacturing of $30 \%$ and $19 \%$.

Finally, it is important to highlight the role of the battery size when evaluating the performance of an EV. In fact, the maximum range of the vehicle is related to the battery capacity, and often calculations are based on the default battery size for each car model, which correspond to the minimum range. Most vehicles are indeed equipped with additional battery capacity to provide the users with additional range. In the analysis presented by the IEA [8], the shift from a standard 200-km range to an extended 
range of $400 \mathrm{~km}$ increases the share of the battery manufacturing on the total lifecycle emissions from 12 to $23 \%$.

\section{Geopolitical Implications}

The increasing role of these minerals, driven by the ongoing global energy transition, will have consequences also on the landscape of energy geopolitics, causing some major transformations. Indeed, energy geopolitics has been traditionally associated to oil, gas and coal, but the increasing role of minerals, essential for the decarbonization, has upheaved new global players and new topics into the energy geopolitics competition.

The decarbonization process generates two main consequences for the energy geopolitics system: it could lead to a changes in inter-state relations, posing at the center of the new energy geopolitical system those countries that have reserves and resources required for the new types of energy sources; and, simultaneously, it increases the geopolitical competition on technological and industrial knowledge essential in transforming these resources. Therefore, rich countries have the opportunity to become part of the global production and value chains necessary for renewable technologies, while leaders in technological innovation are positioned to gain the most from the global energy transformation [89]. Nevertheless, while some features of the energy geopolitics might be transformed by the decarbonization, some others might remain unchanged, for example the issue of security of energy supply. Indeed, concerns over secure and stable supplies will remain, especially because the vast majority of cobalt production is located in weak states such as DRC. In addition, regarding to lithium production, some concerns about security of supply have been expressed following political unrest in South American countries, which are main lithium producers. Therefore, consumers and importers will try to diversify their supplies in order to offset the risk of supply disruptions. In this context, Australia might gain some geopolitical share, attracting new investors and companies in its mining sector. However, they could encounter some obstacles, given the dominant role of China in the country's mining sector.

Precisely, China seems to be the best positioned country in the geopolitics of EVs and minerals, mainly because its dominance in the supply (value) chains. Indeed, China has ensured significant relevance in the value chains of batteries. In the last few years, Chinese companies have become some of the world's largest producers of lithium, through acquisitions of mines from Australia to South America and building plants in China [90]. China's moves are driven by the political commitment to become an industrial leader of EVs and renewable energy sources thanks to a significant political, economic and industrial coordination. Its strong position reinforced concerns over potential disruptions driven by political disagreements, especially since 2010 after China decided to first reduce export quotas of the elements by $40 \%$ and then "unofficially" boycott exports to Japan over an incident near the contested Senkaku/Diaoyu Islands in the East China Sea [91].

Besides competition over material supplies, geopolitical competition among countries has moved to the industrial aspects, especially in those countries where the automotive industry is a key element of the socioeconomic structure. For example, in the EU, traditional auto manufacturing employs around 13 million people, representing $6.1 \%$ of employment. Such countries fear losing their competitiveness or market shares by the lack of battery production capacity. Indeed, the decarbonization process and the advent of EVs driven by climate policies will ultimately affect industrial policies. Therefore, given the growing relevance of these materials for their economic future, Western countries started to look at these resources more strategically. Firstly, they set a list of critical materials for their strategic industries. In 2018, the US published a list of 35 critical minerals that included both lithium and cobalt as well as rare earths. The EU has published its own list that includes cobalt and underscores lithium's criticality for battery technology. Japan maintains a stockpile of minerals that it deems critical and through a government institution it provides equity support or loans to companies for metal resource exploration projects [91]. Lately, they started to develop plans and projects in order to increase the production capacity, gain some competitiveness and reduce the gap with the Asian countries, mostly China. 
In October 2017, the European Commission launched the 'European Battery Alliance', a cooperation platform for key industrial stakeholders, Member States and the European Investment Bank. A key target of the EU is to secure access to raw materials from resource-rich countries outside the EU, while boosting primary and secondary production from European sources [92]. France and Germany took the lead in this effort. A key role in the competition among countries is the construction of 'giga-factories'. Indeed, Asia (and particularly China) dominates the battery production capacity, but the EU and the US have started to plan to build-up their production capacities. BNEF expects European battery manufacturing capacity to top $198 \mathrm{GWh}$ a year by 2023 . That would allow the continent to surpass the $130 \mathrm{GWh}$ a year of North American manufacturing capacity by 2023. However, it will remain difficult to overtake China, which is expected to hit 800 GWh of annual manufacturing capacity by 2023. That will represent about two-thirds of global output. The competition on giga-factories and minerals illustrates the relevance of these elements in the process of decarbonization, that will shape the world's industrial and power structure. Moreover, a further factor that contributed to the increasing concerns over security supply and supply chains is the fact that world economy must face a mounting trend of commercial confrontations, such as the so-called US-China trade war and potentially a reconsideration about global supply chain structures, following the 2020 coronavirus pandemic, leading to abundance of options in order to have a stronger resilience to potential disruptions.

Lastly, the aforementioned geopolitical implications will take place, only if the future deployment and use of EVs are significant. Indeed, the future pathway of EVs use and the future geopolitical configuration are deeply interlinked. EVs deployment and use depend on economic and commercial feasibility; thus, unless EVs are made commercially attractive, car buyers might still buy traditional vehicles (with internal combustion engines). Therefore, policies and incentives still play an important role in the efforts of enhancing EVs use-as Chinese and Norwegian markets show. Particularly, incentives are needed for EVs until battery costs lower-as much as to allow EVs to become cheaper-from a total cost of ownership perspective, than other alternatives [93].

\section{Conclusions}

We believe that the Li-ion batteries can represent a key technology for the decarbonization of the energy system, in particular in the transport sector. Our review highlights five main aspects that will be crucial in the development of Li-ion batteries:

- The evolution and choice of future battery chemistries

- Potential concerns for raw materials availability

- The importance of battery end-of-life and recycling processes

- The need of more detailed data on environmental impacts

- The potential shift of the energy geopolitical equilibrium

To date, Li-ion battery technology has been confirmed as the winning choice for the development of electric mobility in the near future, and mass production has made it possible to exploit the scale economies necessary to reduce production costs. However, further technological and economic developments are foreseeable. In particular, in the short term, increasing energy density and reducing the content of critical raw materials, such as cobalt, will be the main focus of research activities. Currently, safety issues represent the main reason that is limiting the development of Ni-rich technologies.

It is widely accepted that a shortage of raw materials necessary to meet the expected demand of lithium batteries is unlikely, but critical bottlenecks in the short term can emerge due to the quick ramp-up required to mining production. Although lithium production is quite differentiated globally, only some mines are able to respond quickly to changing market dynamics. On the other hand, cobalt production is mostly linked to the DRC mineral production and, therefore, to the political stability of the country. Lastly, the concentration in China of large part of the global refining capacity represents another potential bottleneck for the global battery supply chain. 
End-of-life of depleted batteries remains a crucial aspect, including the opportunity of repurposing the batteries for stationary storage when they are no longer usable for EVs, but a final recycling stage to recover the available materials should be envisaged. Recycling processes maturity still needs to be improved, and their potential impacts and benefits need further studies to assess meaningful results. The deployment of effective recycling solutions at scale will need a proper policy support to trigger the value of recycling by creating relevant markets and emissions targets.

The development of the lithium battery supply chain at global level makes it difficult to assess the environmental impacts of the production chain. Moreover, few data are available from production sites. The differentiation in production sites, chemical processes, energy mix and cell chemistries and configurations leads to a wide variation in study results. However, our review evidences how, compared to dated articles, more recent studies show a decreasing level of GHG emissions associated with battery pack production: this is primarily linked to a deeper knowledge of the characteristics of commercial-scale factories and to an improvement of production performance.

The increasing role of these minerals will certainly affect inter-state relations, with some geopolitical transformation. Indeed, countries that hold these resources might gain geopolitical power. Thus, some geopolitical concepts will remain unchanged, such as the pursue of security of supply. However, new geopolitical concepts and players might arise in the future. For example, important aspects of the new geopolitical competition might be the industrial and technological aspects which are essential to dominate the new sectors. Nevertheless, the future geopolitical architecture will be shaped only if use and deployment of EVs are substantial. To have substantial use of EVs globally, policies and incentives will be crucial; otherwise, the energy geopolitics will not be deeply transformed.

Author Contributions: All authors conceptualized together the study and contributed at different degrees to all sections of the work. D.S. was responsible for the supply chain of the batteries and its sustainability; M.N. wrote the Introduction and the parts on batteries demand and end-of-life; and P.P.R. focused on the future geopolitics of batteries. All authors contributed to the writing and review of the final paper. All authors have read and agreed to the published version of the manuscript.

Funding: This research received no external funding.

Acknowledgments: The support of Fondazione Eni Enrico Mattei is gratefully acknowledged. We would also like to thank our colleagues Manfred Hafner and Giacomo Falchetta for their help and comments on these topics.

Conflicts of Interest: The authors declare no conflict of interest.

\section{Abbreviations}

The following abbreviations are used in this manuscript:

$\begin{array}{ll}\text { BEV } & \text { Battery electric vehicle } \\ \text { BNEF } & \text { Bloomberg New Energy Finance } \\ \text { DRC } & \text { Democratic Republic of Congo } \\ \text { EVs } & \text { Electric vehicles } \\ \text { GHG } & \text { Greenhouse gas } \\ \text { IEA } & \text { International Energy Agency } \\ \text { IRENA } & \text { International Renewable Energy Agency } \\ \text { LCO } & \text { Lithium cobalt oxide } \\ \text { LDV } & \text { Light-duty vehicle } \\ \text { LFP } & \text { Lithium iron phosphate } \\ \text { LMO } & \text { Lithium manganese oxide } \\ \text { LMP } & \text { Lithium metal polymer } \\ \text { NCA } & \text { Lithium nickel cobalt aluminium oxide } \\ \text { NMC } & \text { Lithium nickel manganese cobalt oxide } \\ \text { PHEV } & \text { Plugin hybrid electric vehicle } \\ \text { RES } & \text { Renewable energy sources }\end{array}$




\section{References}

1. World Health Organization. Ambient Air Pollution: A Global Assessment of Exposure and Burden of Disease; World Health Organization: Geneva, Switzerland, 2016.

2. Zubi, G.; Dufo-López, R.; Carvalho, M.; Pasaoglu, G. The lithium-ion battery: State of the art and future perspectives. Renew. Sustain. Energy Rev. 2018, 89, 292-308. [CrossRef]

3. IRENA. Electricity Storage and Renewables: Costs and Markets to 2030; Technical Report; International Renewable Energy Agency: Abu Dhabi, UAE, 2017.

4. Berckmans, G.; Messagie, M.; Smekens, J.; Omar, N.; Vanhaverbeke, L.; Van Mierlo, J. Cost Projection of State of the Art Lithium-Ion Batteries for Electric Vehicles Up to 2030. Energies 2017, 10, 1314. [CrossRef]

5. White, C.; Thompson, B.; Swan, L.G. Repurposed electric vehicle battery performance in second-life electricity grid frequency regulation service. J. Energy Storage 2020, 28, 101278. [CrossRef]

6. Cusenza, M.A.; Guarino, F.; Longo, S.; Mistretta, M.; Cellura, M. Reuse of electric vehicle batteries in buildings: An integrated load match analysis and life cycle assessment approach. Energy Build. 2019, 186, 339-354. [CrossRef]

7. Tsiropoulos, I.; Tarvydas, D.; Lebedeva, N. Li-Ion Batteries for Mobility and Stationary Storage Applications; EU Publications: Luxembourg, 2018; doi:10.2760/87175. [CrossRef]

8. International Energy Agency. Global EV Outlook 2019; International Energy Agency: Paris, France, 2019.

9. Liu, D.; Xiao, B. Exploring the development of electric vehicles under policy incentives: A scenario-based system dynamics model. Energy Policy 2018, 120, 8-23. [CrossRef]

10. Nykvist, B.; Sprei, F.; Nilsson, M. Assessing the progress toward lower priced long range battery electric vehicles. Energy Policy 2019, 124, 144-155. [CrossRef]

11. Ambrose, H.; Kendall, A.; Lozano, M.; Wachche, S.; Fulton, L. Trends in life cycle greenhouse gas emissions of future light duty electric vehicles. Transp. Res. Part D Transp. Environ. 2020, 81, 102287. [CrossRef]

12. Wenig, J.; Sodenkamp, M.; Staake, T. Battery versus infrastructure: Tradeoffs between battery capacity and charging infrastructure for plug-in hybrid electric vehicles. Appl. Energy 2019, 255, 113787. [CrossRef]

13. Naumanen, M.; Uusitalo, T.; Huttunen-Saarivirta, E.; van der Have, R. Development strategies for heavy duty electric battery vehicles: Comparison between China, EU, Japan and USA. Resour. Conserv. Recycl. 2019, 151, 104413. [CrossRef]

14. Bellocchi, S.; Manno, M.; Noussan, M.; Vellini, M. Impact of Grid-Scale Electricity Storage and Electric Vehicles on Renewable Energy Penetration: A Case Study for Italy. Energies 2019, 12, 1303. [CrossRef]

15. International Energy Agency. World Energy Outlook 2019; International Energy Agency: Paris, France, 2019.

16. Bloomberg NEF. Energy Storage Outlook 2019; Bloomberg: London, UK; New York, NY, USA, 2019.

17. Li, Q.; Chen, J.; Fan, L.; Kong, X.; Lu, Y. Progress in electrolytes for rechargeable Li-based batteries and beyond. Green Energy Environ. 2016. [CrossRef]

18. Francis, C.; Kyratzis, I.; Best, A. Lithium-Ion Battery Separators for Ionic-Liquid Electrolytes: A Review. Adv. Mater. 2020. [CrossRef]

19. Zeng, X.Q.; Li, M.; El-Hady, D.A.; Alshitari, W. Commercialization of Lithium Battery Technologies for Electric Vehicles. Adv. Energy Mater. 2019. [CrossRef]

20. Alves Dias, P.; Blagoeva, D.; Pavel, C.; Arvanitidis, N. Cobalt: Demand-Supply Balances in the Transition to Electric Mobility; JRC Science for Policy Report; EU Publications: Luxembourg, 2018.

21. Energy, A. Current Status and Future Trends of the Global Li-Ion Battery Market; Technical Report; Avicenne Energy: London, UK, 2018.

22. Kim, T.; Song, W.; Son, D.Y.; Ono, L.; Qi, Y. Lithium-ion batteries: Outlook on present, future, and hybridized technologies. J. Mater. Chem. A 2019, 7. [CrossRef]

23. Rapier, R. Why China Is Dominating Lithium-Ion Battery Production. Forbes, 4 August 2019.

24. Lithium Ion Battery Value Chain and Related Opportunities for Europe; JRC Science for Policy Report; EU Publications Office: Luxembourg, 2016.

25. Pillot, C. Current Status and Future Trends for the Lithium-ion Battery Market; Avicenne Energy: London, UK, 2019.

26. Colbourn, R. Europe's Role in the Battery Megafactory Supply Chain; Benchmark Mineral Intelligence: London, UK, 2019. 
27. Wheeler, P.; Teng, Y.; Ogilvy, D. Why Are Battery Companies Investing in Mines? Strategies for Vertical Integration in the Mining Industry; L.E.K Consulting: Melbourne, VIC, Australia, 2019.

28. Future of Batteries-Winner Takes All? Arthur D. Little: Luxembourg, 2018.

29. Habib, K.; Hansdóttir, S.T.; Habib, H. Critical metals for electromobility: Global demand scenarios for passenger vehicles, 2015-2050. Resour. Conserv. Recycl. 2020, 154, 104603. [CrossRef]

30. Mineral Commodity Summaries 2020; U.S. Geological Survey: Reston, VA, USA, 2020.

31. Report on Raw Materials for Battery Applications; Commission Staff Working Document; EU Publications Office: Luxembourg, 2018.

32. Vikström, H.; Davidsson, S.; Höök, M. Lithium availability and future production outlooks. Appl. Energy 2013, 110, 252-266. [CrossRef]

33. Laura Talens Peiró, G.V.M.; Ayres, R.U. Lithium: Sources, Production, Uses, and Recovery Outlook. JOM 2013. [CrossRef]

34. Grosjean, C.; Miranda, P.H.; Perrin, M.; Poggi, P. Assessment of world lithium resources and consequences of their geographic distribution on the expected development of the electric vehicle industry. Renew. Sustain. Energy Rev. 2012, 16, 1735-1744. [CrossRef]

35. Schüler, D.; Dolega, P.; Degreif, S. Social, Economic and Environmental Challenges in Primary Lithium and Cobalt Sourcing for the Rapidly Increasing Electric Mobility Sector; European Policy Brief; Oeko-Institut: Freiburg, Germany, 2018.

36. Narins, T.P. The battery business: Lithium availability and the growth of the global electric car industry. Extr. Ind. Soc. 2017, 4, 321-328. [CrossRef]

37. Choubey, P.K.; Seuk Kim, M.; Srivastava, R.R.; Chun Lee, J.; Lee, J.Y. Advance review on the exploitation of the prominent energy-storage element: Lithium. Part I: From mineral and brine resources. Miner. Eng. 2016, 89, 119-137. [CrossRef]

38. Flexer, V.; Baspineiro, C.F.; Galli, C.I. Lithium recovery from brines: A vital raw material for green energies with a potential environmental impact in its mining and processing. Sci. Total Environ. 2018, 639, 1188-1204. [CrossRef]

39. Choubey, P.K.; Chung, K.S.; Seuk Kim, M.; Chun Lee, J.; Srivastava, R.R. Advance review on the exploitation of the prominent energy-storage element Lithium. Part II: From sea water and spent lithium ion batteries (LIBs). Miner. Eng. 2017, 110, 104-121. [CrossRef]

40. DERA Rohstoffinformation Nr. 33: Rohstoffrisikobewertung Lithium; Deutsche Rohstoffagentur (DERA): Berlin, Germany, 2017.

41. Maxwell, P.; Mora, M. Lithium and Chile: Looking back and looking forward. Miner. Econ. 2019. [CrossRef]

42. Mineral Commodity Summaries 2016; U.S. Geological Survey: Reston, VA, USA, 2016.

43. Martin, G.; Rentsch, L.; Höck, M.; Bertau, M. Lithium market research-Global supply, future demand and price development. Energy Storage Mater. 2017, 6, 171-179. [CrossRef]

44. Speirs, J.; Contestabile, M.; Houari, Y.; Gross, R. The future of lithium availability for electric vehicle batteries. Renew. Sustain. Energy Rev. 2014, 35, 183-193. [CrossRef]

45. Sun, X.; Hao, H.; Zhao, F.; Liu, Z. Tracing global lithium flow: A trade-linked material flow analysis. Resour. Conserv. Recycl. 2017, 124, 50-61. [CrossRef]

46. Cobalt-for Strength and Color; U.S. Geological Survey: Reston, VA, USA, 2011.

47. Gulley, A.L.; McCullough, E.A.; Shedd, K.B. China's domestic and foreign influence in the global cobalt supply chain. Resour. Policy 2019, 62, 317-323. [CrossRef]

48. Shedd, K.; McCullough, E.; Bleiwas, D. Global trends affecting the supply security of cobalt. Min. Eng. 2017, $69,37-42$.

49. Campagnol, N.; Hoffman, K.; Lala, A.; Ramsbottom, O. The Future of Nickel: A Class Act; McKinsey\&Company: New York, NY, USA, 2017.

50. Schmidt, T.; Buchert, M.; Schebek, L. Investigation of the primary production routes of nickel and cobalt products used for Li-ion batteries. Resour. Conserv. Recycl. 2016, 112, 107-122. [CrossRef]

51. Ballinger, B.; Schmeda-Lopez, D.; Kefford, B.; Parkinson, B.; Stringer, M.; Greig, C.; Smart, S. The vulnerability of electric-vehicle and wind-turbine supply chains to the supply of rare-earth elements in a 2-degree scenario. Sustain. Prod. Consum. 2020, 22, 68-76. [CrossRef]

52. Olivetti, E.; Ceder, G.; Gaustad, G.; Fu, X. Lithium-Ion Battery Supply Chain Considerations: Analysis of Potential Bottlenecks in Critical Metals. Joule 2017, 1, 229-243. [CrossRef] 
53. Duan, J.; Tang, X.; Dai, H.; Yang, Y.; Wu, W.; Wei, X.; Huang, Y. Building Safe Lithium-Ion Batteries for Electric Vehicles: A Review. Electrochem. Energy Rev. 2020, 3, 1-42. [CrossRef]

54. Gandoman, F.H.; Jaguemont, J.; Goutam, S.; Gopalakrishnan, R.; Firouz, Y.; Kalogiannis, T.; Omar, N.; Mierlo, J.V. Concept of reliability and safety assessment of lithium-ion batteries in electric vehicles: Basics, progress, and challenges. Appl. Energy 2019, 251, 113343. [CrossRef]

55. Duffner, F.; Wentker, M.; Greenwood, M.; Leker, J. Battery cost modeling: A review and directions for future research. Renew. Sustain. Energy Rev. 2020, 127, 109872. [CrossRef]

56. Wentker, M.; Greenwood, M.; Leker, J. A Bottom-Up Approach to Lithium-Ion Battery Cost Modeling with a Focus on Cathode Active Materials. Energies 2019, 12, 504. [CrossRef]

57. Steen, M.; Lebedeva, N.; Di Persio, F.; Boon-Brett, L. EU Competitiveness in Advanced Li-ion Batteries for E-Mobility and Stationary Storage Applications-Opportunities and Actions; JRC Science for Policy Report; EU Publications Office: Luxembourg, 2017.

58. Nitta, N.; Wu, F.; Lee, J.T.; Yushin, G. Li-ion battery materials: Present and future. Mater. Today 2015, 18, 252-264. [CrossRef]

59. Vandepaer, L.; Cloutier, J.; Amor, B. Environmental impacts of Lithium Metal Polymer and Lithium-ion stationary batteries. Renew. Sustain. Energy Rev. 2017, 78, 46-60. [CrossRef]

60. Research and Markets. Global Automotive Solid-State Battery Market 2019-2030; Technical Report; Research and Markets: Dublin, Ireland, 2019.

61. Liu, Y.; Wang, R.; Lyu, Y.; Li, H.; Chen, L. Rechargeable Li-CO ${ }^{2}-\mathrm{O}^{2}(2 \div 1)$ battery and Li/CO $\mathrm{CO}^{2}$ battery. Energy Environ. Sci. 2014, 7, 677-681. [CrossRef]

62. Takechi, K.; Shiga, T.; Asaoka, T. A Li-O ${ }^{2} / \mathrm{CO}^{2}$ battery. Chem. Commun. 2011, 47, 3463-3465. [CrossRef]

63. Canals Casals, L.; Rodríguez, M.; Corchero, C.; Carrillo, R.E. Evaluation of the End-of-Life of Electric Vehicle Batteries According to the State-of-Health. World Electr. Veh. J. 2019, 10, 63. [CrossRef]

64. Chen, M.; Ma, X.; Chen, B.; Arsenault, R.; Karlson, P.; Simon, N.; Wang, Y. Recycling End-of-Life Electric Vehicle Lithium-Ion Batteries. Joule 2019, 3, 2622-2646. [CrossRef]

65. Lai, X.; Qiao, D.; Zheng, Y.; Yi, W. A Novel Screening Method Based on a Partially Discharging Curve Using a Genetic Algorithm and Back-Propagation Model for the Cascade Utilization of Retired Lithium-Ion Batteries. Electronics 2018, 7, 399. [CrossRef]

66. Li, X.; Shu, X.; Shen, J.; Xiao, R.; Yan, W.; Chen, Z. An On-Board Remaining Useful Life Estimation Algorithm for Lithium-Ion Batteries of Electric Vehicles. Energies 2017, 10, 691. [CrossRef]

67. Madlener, R.; Kirmas, A. Economic Viability of Second Use Electric Vehicle Batteries for Energy Storage in Residential Applications. Energy Procedia 2017, 105, 3806-3815. [CrossRef]

68. Heelan, J.; Gratz, E.; Zheng, Z.; Wang, Q.; Chen, M.; Apelian, D.; Wang, Y. Current and Prospective Li-Ion Battery Recycling and Recovery Processes. JOM 2016, 68, 2632-2638. [CrossRef]

69. Sieber, T.; Ducke, J.; Rietig, A.; Langner, T.; Acker, J. Recovery of Li(Ni0.33Mn0.33Co0.33)O2 from Lithium-Ion Battery Cathodes: Aspects of Degradation. Nanomaterials 2019, 9, 246. [CrossRef]

70. Analysis of the Climate Impact of Lithium-Ion Batteries and How to Mesure It; Transport \& Environment: Brussels, Belgium, 2019.

71. Emilson, E.; Dahllöf, L. Lithium-Ion Vehicle Battery Production; Technical Report; IVL Swedish Environmental Research Institute: Stockholm, Sweden, 2019.

72. Hao, H.; Mu, Z.; Jiang, S.; Liu, Z.; Zhao, F. GHG Emissions from the Production of Lithium-Ion Batteries for Electric Vehicles in China. Sustainability 2017, 9, 504. [CrossRef]

73. Ciez, R.E.; Whitacre, J.F. Examining different recycling processes for lithium-ion batteries. Nat. Sustain. 2019, 2, 148-156. [CrossRef]

74. Peters, J.F.; Baumann, M.; Zimmermann, B.; Braun, J.; Weil, M. The environmental impact of Li-Ion batteries and the role of key parameters-A review. Renew. Sustain. Energy Rev. 2017, 67, 491-506. [CrossRef]

75. Dai, Q.; Kelly, J.C.; Elgowainy, A. Cobalt Life Cycle Analysis Update for the GREET Model; Argonne National Laboratory: Chicago, IL, USA, 2018.

76. Dai, Q.; Kelly, J.C.; Gaines, L.; Wang, M. Life Cycle Analysis of Lithium-Ion Batteries for Automotive Applications. Batteries 2019, 5, 48. [CrossRef]

77. Notter, D.A.; Gauch, M.; Widmer, R.; Wager, P.; Stamp, A.; Zah, R.; Althaus, H.J. Contribution of Li-Ion Batteries to the Environmental Impact of Electric Vehicles. Environ. Sci. Technol. 2010, 44, 6550-6556. [CrossRef] 
78. Majeau-Bettez, G.; Hawkins, T.R.; Strømman, A.H. Life Cycle Environmental Assessment of Lithium-Ion and Nickel Metal Hydride Batteries for Plug-In Hybrid and Battery Electric Vehicles. Environ. Sci. Technol. 2011, 45, 4548-4554. [CrossRef]

79. Li, B.; Li, J.; Yuan, C. Life Cycle Assessment of Lithium Ion Batteries with Silicon Nanowire Anode for Electric Vehicles. In Proceedings of the 2013 International Symposium on Sustainable Systems \& Technology, Cincinnati, OH, USA, 15-17 May 2013.

80. Ellingsen, L.A.W.; Majeau-Bettez, G.; Singh, B.; Srivastava, A.K.; Valøen, L.O.; Strømman, A.H. Life Cycle Assessment of a Lithium-Ion Battery Vehicle Pack. J. Ind. Ecol. 2013, 18, 113-124. [CrossRef]

81. Kim, H.C.; Wallington, T.J.; Arsenault, R.; Bae, C.; Ahn, S.; Lee, J. Cradle-to-Gate Emissions from a Commercial Electric Vehicle Li-Ion Battery: A Comparative Analysis. Environ. Sci. Technol. 2016, 50, 7715-7722. [CrossRef]

82. Zackrisson, M.; Avellán, L.; Orlenius, J. Life cycle assessment of lithium-ion batteries for plug-in hybrid electric vehicles-Critical issues. J. Clean. Prod. 2010. [CrossRef]

83. Dunn, J.B.; Gaines, L.; Sullivan, J.; Wang, M.Q. The Impact of Recycling on Cradle-to-Gate Energy Consumption and Greenhouse Gas Emissions of Automotive Lithium-Ion Batteries. Environ. Sci. Technol. 2012. [CrossRef]

84. Product Environmental Footprint Category Rules for High Specific Energy Rechargeable Batteries for Mobile Applications; Technical Report; EU Publications Office: Luxembourg, 2018.

85. Jiang, S.; Zhang, L.; Li, F.; Hua, H.; Liu, X.; Yuan, Z.; Wu, H. Environmental impacts of lithium production showing the importance of primary data of upstream process in life-cycle assessment. J. Environ. Manag. 2020, 262, 110253. [CrossRef]

86. Le Varlet, T.; Schmidt, O.; Gambhir, A.; Few, S.; Staffell, I. Comparative life cycle assessment of lithium-ion battery chemistries for residential storage. J. Energy Storage 2020, 28, 101230. [CrossRef]

87. Marques, P.; Garcia, R.; Kulay, L.; Freire, F. Comparative life cycle assessment of lithium-ion batteries for electric vehicles addressing capacity fade. J. Clean. Prod. 2019, 229, 787-794. [CrossRef]

88. Transport \& Environment. How Clean Are Electric Cars? Technical Report; Transport \& Environment: Brussels, Belgium, 2020.

89. IRENA. A New World: The Geopolitics of the Energy Transition; Technical Report; International Renewable Energy Agency: Abu Dhabi, UAE, 2019.

90. Sanderson, H. Electric cars: China powers the battery supply chain. Financial Times, 2019. Available online: https:/ / www.ft.com/ content/455fe41c-7185-11e9-bf5c-6eeb837566c5 (accessed on 15 April 2020).

91. Kalantzakos, S. The Geopolitics of Critical Minerals; IAI PAPERS; 2019; Volume 19. Available online: https:/ / www.iai.it/sites/default/files/iaip1927.pdf (accessed on 12 April 2020).

92. Europe on the Move-Sustainable Mobility for Europe: Safe, Connected and Clean; COM(2018) 293; EU Publications Office: Luxembourg, 2018.

93. Christian Thiel, A.T.; Jäger-Waldau, A. Will Electric Vehicles Be Killed (again) or Are They the Next Mobility Killer App? Energies 2020. [CrossRef]

(C) 2020 by the authors. Licensee MDPI, Basel, Switzerland. This article is an open access article distributed under the terms and conditions of the Creative Commons Attribution (CC BY) license (http:/ / creativecommons.org/licenses/by/4.0/). 